\title{
Determinants of Contractual Completeness in Franchising
}

\section{George Hendrikse and Josef Windsperger}

Forthcoming as book chapther in:

Tuunanen, M., G. Cliquet, G. Hendrikse, J. Windsperger,

"New Developments in the Theory of Networks: Franchising, Cooperatives and Alliances", Physica-

Verlag, Heidelberg, forthcoming.

\begin{tabular}{|l|l|}
\hline \multicolumn{2}{|l|}{ ERIM REPORT SERIES RESEARCH IN MANAGMENT } \\
\hline ERIM Report Series reference number & ERS-2010-017-ORG \\
\hline Publication & April 2010 \\
\hline Number of pages & 20 \\
\hline Persistent paper URL & http://hdl.handle.net/1765/19424 \\
\hline Email address corresponding author & ghendrikse@rsm.nl \\
\hline Address & Erasmus Research Institute of Management (ERIM) \\
& RSM Erasmus University / Erasmus School of Economics \\
& Erasmus Universiteit Rotterdam \\
& P.O.Box 1738 \\
& 3000 DR Rotterdam, The Netherlands \\
& Phone: + 31104081182 \\
& Fax: $\quad+31104089640$ \\
& Email: info@erim.eur.nl \\
& Internet: $\quad$ www.erim.eur.nl \\
\hline
\end{tabular}

Bibliographic data and classifications of all the ERIM reports are also available on the ERIM website: www.erim.eur.nl 


\section{ERASMUS RESEARCH INSTITUTE OF MANAGEMENT}

\section{REPORT SERIES}

\section{RESEARCH IN MANAGEMENT}

\begin{tabular}{|l|l|}
\hline ABSTRACT AND KEYWORDS \\
\hline Abstract & $\begin{array}{l}\text { The aim of the study is to explain the determinants of contractual completeness in franchise } \\
\text { relationships by formulating and testing various propositions derived from transaction cost } \\
\text { theory, agency theory, property rights theory, organizational capability theory and relational view } \\
\text { of governance. The degree of contractual completeness depends on behavioural uncertainty } \\
\text { (negatively), trust (positively), franchisees' specific investments (negatively), environmental } \\
\text { uncer-tainty (negatively), intangibility of system specific know-how (negatively) and contract } \\
\text { design capabilities (positively). The hypotheses are tested with a data base consisting of 52 } \\
\text { franchise systems in Austria. The empirical results support the hypotheses regarding } \\
\text { behavioural uncertainty, trust and intangible system-specific know-how. }\end{array}$ \\
\hline Free Keywords & \begin{tabular}{l} 
franchising, contractual completeness \\
\hline Availability
\end{tabular} \\
$\begin{array}{ll}\text { The ERIM Report Series is distributed through the following platforms: } \\
\text { Academic Repository at Erasmus University (DEAR), DEAR ERIM Series Portal } \\
\text { Social Science Research Network (SSRN), SSRN ERIM Series Webpage } \\
\text { Research Papers in Economics (REPEC), REPEC ERIM Series Webpage }\end{array}$ \\
\hline Classifications & $\begin{array}{l}\text { The electronic versions of the papers in the ERIM report Series contain bibliographic metadata } \\
\text { by the following classification systems: } \\
\text { Library of Congress Classification, (LCC) LCC Webpage } \\
\text { Journal of Economic Literature, (JEL), JEL Webpage } \\
\text { ACM Computing Classification System CCS Webpage } \\
\text { Inspec Classification scheme (ICS), ICS Webpage }\end{array}$ \\
\hline
\end{tabular}




\title{
Determinants of Contractual Completeness in Franchising
}

\author{
George Hendrikse and Josef Windsperger*
}

\begin{abstract}
The aim of the study is to explain the determinants of contractual completeness in franchise relationships by formulating and testing various propositions derived from transaction cost theory, agency theory, property rights theory, organizational capability theory and relational view of governance. The degree of contractual completeness depends on behavioural uncertainty (negatively), trust (positively), franchisees' specific investments (negatively), environmental uncertainty (negatively), intangibility of system specific know-how (negatively) and contract design capabilities (positively). The hypotheses are tested with a data base consisting of 52 franchise systems in Austria. The empirical results support the hypotheses regarding behavioural uncertainty, trust and intangible systemspecific know-how.
\end{abstract}

\footnotetext{
* George Hendrikse, Rotterdam School of Management, Erasmus University, P.O. Box 1738, 3000 DR Rotterdam, 00-31-10-4088660, The Netherlands, ghendrikse@rsm.nl; Josef Windsperger, Center for Business Studies, University of Vienna, Brünner Str. 72, A- 1210 Vienna, Austria, josef.windsperger@univie.ac.at.
} 


\section{Introduction}

Under bounded rationality and opportunism complete contracts do not exist between the network partners (Williamson 1975; Hadfield 1990; Scott 2006). In recent years researchers in organizational economics and strategic management have examined the question about the efficient contractual design (e.g. Joskow 1985; Luo 2002; Kalnins and Meyer 2004; Arino and Reuer 2005; Reuer et al. 2006; Ryall and Sampson 2006; Mayer and Argyres 2004; Mellewigt et al. 2007; Mesquita and Brush 2008; Hendrikse and $\mathrm{Hu}$ 2009; Hendrikse and Windsperger 2009). Researchers in organizational economics have tried to explain the degree of contractual completeness by applying transaction costs and property rights reasoning (Crocker and Reynolds 1993; Crocker and Masten 1991; Saussier 2000; Bernheim and Whinston 1998; Al-Najjar 1995; Masten and Saussier 2000). Researchers in strategic management have examined contractual complexity that is closely related to contractual incompleteness (e.g. Barthelemy and Quelin 2006; Reuer and Arino 2007; Hansen and Higgins 2007; Hagedoorn and Hesen 2007). In organizational economics contractual completeness is a concept derived from a complete contract situation. A complete contract specifies all actions to be taken and payments made under every possible environmental situation (Milgrom and Roberts 1992; Bolton and Dewatripont 2005). In the 1990s, the first generation of incomplete contracting theories (e.g. Grossman and Hart 1986; Hart and Moore 1990) explain incompleteness by high enforcement costs due to exogenous verifiability constraints in the contract execution period (Egglestone et al. 2000, 119; Scott and Triantis 2005). More recently, the second generation of incomplete contracting theories (e.g. Hart and Moore 2008; Tirole 2009; Bolton and FaureGrimaud 2009) argues that incompleteness of contracts result primarily from adaptation and endogenous verifiability problems under bounded rationality of the contract partners. Under uncertainty/complexity and bounded rationality (Williamson 1975) as well as intangibility of knowledge, the network partners are unable to specify all actions to be taken and payments made under every possible environmental situation. In this situation, the contract design is an adaptation mechanism (incentive and information processing mechanism) that assigns specific rights and control rights in order to regulate the transactions between the partners (Simon 1951; Gibbons 2005; Baker et al. 2009).

Starting from this adaptation view of contract design, the objective of our paper is to develop a theoretical foundation of the concept of contractual completeness and to examine the determinants of contractual completeness in franchising by testing hypotheses derived from transaction costs, agency theory, property rights, relational governance view of governance and organizational capabilities theory. First, based on the transaction cost theory we argue that completeness varies negatively with the franchisee's specific investments and environmental uncertainty. Franchisee's specific investments increase their quasi-rents and hence the selfenforcing range of contracts, and environmental uncertainty prevents the franchisor from specifying detailed contract terms. Second, by applying the agencytheoretical view, we argue that contractual completeness varies negatively with 
monitoring difficulties due to behavioural uncertainty. Third, we examine the property rights hypothesis that completeness varies negatively with intangibility of the franchisor's system-specific assets. Forth, based on the relational view of governance, we investigate the relationship between trust and the degree of contractual completeness. The complementarity hypothesis states that trust increases knowledge sharing and enables the franchisor to design more complete contracts; on the other hand, according to the substitutability hypothesis, trust decreases relational risks and results in less complete contracts. Finally, based on the organizational capability view, we examine the relationship between contract design capabilities and contractual completeness. We argue that higher contract design capabilities result in a higher degree of contractual completeness. These hypotheses are tested by using data from the Austrian franchise sector.

The article is organized as follows: Section two investigates the concept of contractual incompleteness. In section three we develop the agency cost hypothesis, the hypotheses based on the relational view of governance, and the property rights, the transactions cost hypotheses and the organizational capabilities hypothesis. Finally in section four we test these hypotheses by using data from Austria.

\section{Contractual Completeness}

Recent empirical studies on completeness and complexity of contracts show that contractual completeness is a heterogeneous concept without sufficient theoretical foundation (e. g. Parkhe 1993; Saussier 2000; Reuer and Arino 2002; 2007; Ryall and Sampson 2006; Furlotti 2007; Mezquita and Brush 2008). In the following, first we develop the concept of contractual completeness and second we examine the relationship between completeness and complexity of contracts.

\subsection{Contractual Completeness and Decision Rights}

Designing an efficient contract refers to the question of formulating and assigning specific and residual rights to the contract partners. Specific rights refer to the detailed specification of decision actions in the ex ante period and residual rights refer to the planning of decision procedures which enable decision making about specific actions in the ex post period. The partner who has non-contractible knowledge that generates the residual surplus should have residual decision rights, and the partner who has contractible knowledge should have specific decision rights that are explicitly stipulated in contracts (Demsetz 1998). Complete contract refers to the case where all actions are specified in a comprehensive contract covering every possible environmental situation. In this situation only specific rights are included in the contract. Incomplete contracts refer to the situation in which the agents cannot fully specify the decision actions (contractual obligations) under 
every possible environmental situation. In this case, specific and residual rights are formulated and assigned in the contract. There is a trade-off on the choice between specific rights (sDR) and residual rights (rDR) which is determined by the contractibility of knowledge. When contractability is low, a low portion of specific rights and a high portion of residual rights are assigned to the partners, and when contractibility of knowledge is high, a high portion of specific and a low portion of residual rights are specified in contracts. The ratio between specific and residual rights of the partners defines the degree of contractual completeness: $\mathrm{sDR} / \mathrm{rDR}$. The higher the portion of specific rights compared to residual rights specified in the contract, the higher is the degree of contractual completeness; and the higher the portion of residual rights compared to specific rights, the lower is the degree of contractual completeness. Hence a contract is characterized by a low degree of completeness under a low contractibility of knowledge, and a contract is characterized by a high degree of completeness under a high contractibility of knowledge. This approach is compatible with the adaptability view of governance (Simon 1951; Gibbons 2005) that formulates a trade-off between planning of decision actions (formulating specific rights) and the planning of decision procedures (assigning residual rights) (Bolton and Faure-Grimaud 2005). A similar trade-off is well known in the regulation literature on the choice between rules and standards (Kaplow 1992; Scott and Triantis 2005).

\section{$2.2 \quad$ Relationship between Completeness and Complexity}

After defining contractual completeness we address the question: what is the relationship between contractual complexity and contractual completeness? Recent studies on contractual complexities show that complexity is a heterogeneous concept (e.g. Poppo and Zenger 2002; Arino and Reuer 2005; Reuer and Arino 2007; Hagedoorn and Hesen 2008; Barthelemy and Quelin 2006). Although these studies differ widely in their approach and definition of complexity, the main characteristics of complexity concept can be defined as follows: Complex contracts have detailed specification of promises, obligations, responsibilities to be performed, procedures for monitoring and dispute resolution and determine in detail outcomes or outputs to be delivered. Compared to our completeness concept (sDR/rDR), complexity can be defined by the sum of contract provisions consisting of both specific decision rights (as outcome planning) and residual decision rights (as procedural planning) (sDR + rDR). Hence completeness and complexity are related as follows: A more complex contract can be both more or less complete. If the contract has a higher number of detailed provisions regarding the partners' actions in different environmental situations and a low number of provisions regarding residual decision rights, the contract has a high degree of completeness and a high degree of complexity. On the other hand, if the contract has a high number of provisions regarding the assignment of residual decision rights and a low number of provisions regarding specific rights, the contract has a high degree of complexity, but a low degree of completeness. Therefore, complexity and completeness only 
go hand-in-hand when the use of assets can be specified in detail in a contract due to high contractibility of knowledge. On the other hand, complexity and completeness are negatively related when the use of assets is costly and difficult to specify in a contract due to low contractibility of knowledge, but in this situation the contract specifies in detail the assignment of residual decision rights. Therefore, we do not agree with Arino and Reuer (2005) that "a contract with more specific and detailed terms is more complete than one with less specific and detailed terms".

\section{Determinants of Contractual Completeness in Franchising}

Now we examine the determinants of contractual completeness in franchising by applying transaction costs theory, agency theory, property rights theory, organizational capabilities theory and the relational view of governance.

\subsection{Transaction Cost Theory}

\section{Environmental Uncertainty}

According to the transaction cost theory (Williamson 1975, 1985), environmental uncertainty influences the contract design as governance structure. Transaction costs arise due to bounded rationality under a complex and changing environment resulting in high environmental uncertainty (market, cultural and institutional uncertainty). Environmental uncertainty prevents the franchisor from setting detailed contract terms and hence it increases the need for ex-post adaptations by allocating residual decision rights. The greater the environmental uncertainty, the less complete is the franchise contract and the more residual rights and the less specific decision rights are assigned to the franchise partners.

\section{Transaction-specific Investments}

According to the transaction cost theory, specific investments results in quasirents that can be expropriated by the less dependent partner (Williamson 1985; Klein et al. 1978). In franchising, both the franchisor and the franchisee have to undertake high transaction-specific investments that increase bilateral dependency (Windsperger 1994). When the franchisor's and the franchisee's specific investments result in high quasi-rents, they likely exceed the potential hold-up gain from opportunistic behaviour, thereby increasing the self-enforcing range of contracts (Klein 1996; Klein and Murphy 1997). In this situation, the hostage effect of specific investments motivates both partners to behave cooperatively in order to realize the relationship-specific quasi-rents. Consequently, the bonding effect of high 
bilateral specific investments increases the self-enforcing range of contract and reduces the requirements for specifying detailed contract terms. We can derive the following testable hypotheses from this transaction cost view:

H1a: Contractual completeness is negatively related with environmental uncertainty

H1b: Contractual completeness is negatively related with the franchisee's specific investments.

\subsection{Agency Theory}

According to the agency theory (e.g. Lafontaine 1992; Lafontaine and Slade 1998), asymmetric information and opportunism result in high agency costs. The franchisor has two possibilities of reducing agency costs: On the one hand, to reduce the residual loss by increasing monitoring activities and performance measurement and, on the other hand, by allocating a higher fraction of residual decision rights to the franchisees (Brickley et al. 2003). The higher the behavioural uncertainty (due to moral hazard and adverse selection), the more residual rights should be transferred to the local entrepreneurs, and the less specific rights are formulated in contracts. Consequently, behavioural uncertainty results in measurement difficulties under a multitasking environment and hence in a lower degree of contractual completeness (Holmstrom and Milgrom 1991; Bernheim and Whinston 1998; Egglestone et al. 2000, 110). We derive the following hypothesis:

H2: Contractual completeness varies negatively with behavioural uncertainty.

\subsection{Property Rights Theory}

According to the property rights approach, intangibility (non-contractibility) of knowledge assets results in allocating residual decision rights to the network partners (Aghion et al. 2004; Lerner and Malmendier 2010; Windsperger 2009). The relationship between the intangibility of knowledge assets and the degree of contractual completeness can be stated by the following proposition: The higher the intangibility of the partner-specific knowledge, the greater is the difficulty for the franchisor to explicitly specify the use of system-specific and local market knowhow in the contract, the lower is the ratio between specific and residual decision rights, and hence the lower is the degree of contractual completeness. We formulate the following hypothesis:

H3: Contractual completeness is negatively related with intangible system-specific assets. 


\subsection{The Relational View of Governance}

Under the relational view of governance (Dyer and Singh 1998; Dyer and Chu 2000; Gulati and Nickerson 2008; Mellewigt et al. 2007), there are two perspectives on the impact of trust on the use of contractual provisions: (a) Substitutability view: Knowledge-based trust is a substitute for formal contractual planning (Gulati 1995; Yu et al. 2006). Trust mitigates the contractual hazards due to lower relational risk (Roberts 2000) and hence reduces the extent of formal contract planning. Consequently, the franchisors are likely to use less complete contracts when trust exists between the network partners. (b) Complementarity view: Trust facilitates interorganizational knowledge sharing and enables the formulation of more refined contract terms as "reference points" (Hart and Moore 2008) that determine the boundaries of the self-enforcing range of the contracts (Seppänen et al. 2007; Blomqvist et al. 2005; Klein 1996). Consequently, under a high level of trust the franchisor uses more complete contracts because trust creates an incentive for intense and open information sharing. We derive the following hypothesis:

H4a: Substitutability view: Contractual completeness is negatively related with trust.

H4b: Complementarity view: Contractual completeness is positively related with trust.

\subsection{Organizational Capability View}

The organizational capability view argues that firm-specific capabilities result in competitive advantage through efficient knowledge creation and knowledge exploitation (Nonaka 1994; Teece 2007; Helfat et al. 2007). In franchising, franchisors develop contract design capabilities through interorganizational learning (Argyres and Meyer 2007). Prior relationships may allow for the design of more complete contracts because the partners learn what they need to specify in contracts thereby developing contract design capabilities (Mayer and Argyres 2004; Ryall and Sampson 2006; Argyres et al. 2007; Bolton and Faure-Grimaud 2009). The older the franchise company, the more the franchisors learn about the application of system-specific and the local market knowlege, and the higher are the franchisor's contract design capabilities, i. e. the capabilities to specify more refined contract. We formulate the following hypothesis:

H5: Contractual completeness is positively related with interorganizational learning. 


\section{$4 \quad$ Empirical Analysis}

\subsection{Sample and Data Collection}

The empirical setting for testing these hypotheses is the franchising sector in Austria. We started our empirical work by obtaining the list of all franchise systems in Austria from the Austrian Franchise Association (AFA). AFA identified a total of 260 franchised systems in Austria in 2004. After several preliminary steps in questionnaire development, including interviews with franchisors and franchise consultants and the representatives of the AFA, the final version of the questionnaire was sent out by mail to the general managers of the franchise systems in June 2005 and September 2005. The questionnaire took approximately 15 minutes to complete on average. We received 52 completed responses; hence the response rate is $20 \%$. This low response rate might be due to the relatively long questionnaire ( 7 pages). The general managers (CEOs) as respondents to the survey were the key informants of the franchise systems. Key informants should occupy roles that make them knowledgeable about the issues being researched (John and Reve 1982). Since the general managers as top decision makers in the franchise systems are involved in all contractual decisions (including the design of franchise contracts), they were judged to be the most suitable respondents.

In implementing the survey we took several steps to ensure a good response rate, ranging from including a support letter from the president of the Austrian Franchise Association to conducting multiple follow-ups with non-respondents (Fowler 1993). We examined the non-response bias by investigating whether the results obtained from analysis were driven by differences between the group of respondents and the group of non-respondents. Non-response bias was estimated by comparing early versus late respondents (Armstrong and Overton 1977), where late respondents serve as proxies for non-respondents. No significant differences emerged between the two groups of respondents. In addition, based on Podsakoff et al. (2003), we used Harman's single-factor test to examine whether a significant amount of common method variance exists in the data. After we conducted factor analysis on all items and extracted more than one factor with eigenvalues greater than one, we felt confident that common method variance is not a serious problem in our study.

\subsection{Measurement}

To test the hypotheses the following variables are important: contractual completeness, transaction-specific investments of the franchisee, behavioral uncertainty, intangible system-specific assets, environmental uncertainty, trust and contract design capabilities (see appendix). 
Degree of contractual completeness

The indicator of COMPLETENESS is a proxy for the degree of contractual completeness defined by the ratio between specific and residual decision rights. Hence it addresses the extent to which specific rights of the franchisor and the franchisee are included in the contract. The general managers were asked to rate the degree of contractual completeness on a five-point scale: "The cooperation between the franchisor and the franchisee is regulated in a detailed manner in the contract”. The higher the indicator, the higher is the degree of contractual completeness.

Transaction specific investments of the franchisee

Transaction specific investments (SPECIFIC_INVESTMENTS) reduce the requirements for formulating specific contract terms because they increase the selfenforcing range of the contracts (Klein 1996). The franchisee's transactionspecific investments are measured by the initial investments (including initial fees).

Behavioral uncertainty

Behavioral uncertainty (BEHAV_UNCERTAINTY) results in measurement difficulties and monitoring costs under asymmetric information. Higher monitoring costs are negatively related to contractual completeness (Egglestone et al. 2000, 110). Consistent with previous studies we operationalize behavioral uncertainty with a four-item scale (e.g. Anderson 1985; John, Weitz 1989; Heide, John 1990) (see appendix). The reliability of this scale was assessed by Cronbach's alpha (0.83).

\section{Environmental uncertainty}

According to Crocker and Reynolds (1993) and Ryall and Sampson (2009), contract duration is positively related with environmental uncertainty. We use contract duration as indicator of environmental uncertainty (ENV_UNCERTAINTY). This indicator represents the difficulty regarding preplanning of the franchisor's and franchisees' actions under a complex and changing environment. The longer the contract duration, the more difficult and costly is the planning of decision actions in the ex ante period, and the lower is the degree of contractual completeness.

Intangible system-specific assets

Based on indicators used in earlier studies (e.g. Windsperger 2004) we used training days (franchisees and franchisee's employees) (INTANGIBLE_SYSTEM ASSETS) as proxy for the franchisor's intangible system-specific assets. The number of training days is an indicator for intangibility of the franchisor's systemspecific know-how. The assumption behind this measure is that as intangibility of knowledge assets increases, so does the number of days of face-to-face interaction. Consistent with the view of Simonin (1999a,b), the higher the degree of intangibility, the more tacit (less contractible) is the system-specific know-how, and the more personal knowledge transfer methods are used, such as meetings, coaching and training. 
Trust

Under the relational view of governance trust may be a substitute for or complement of formal contract planning. Trust is a very heterogeneous concept (e. g. Levin and Cross 2004; Seppänen et al. 2007; Lazzarini et al. 2008). We operationalize trust (TRUST) with a four-item scale (see Appendix) (Cronbach alpha $=0.86$ ).

\section{Contract Design Capabilities}

Prior relationships may allow for the design of more complete contracts because the franchisor develops contract design capabilities (Argyres et al. 2007; Bolton and Faure-Grimaud 2009). Experience of the franchise company (as number of years since the opening of the first franchise outlet in Austria) is a proxy for interorganizational learning and developing contract design capabilities (CDCAPABILITIES).

\subsection{Results}

Table 1 presents the descriptive data for the sample in Austria.

Table 1. Descriptive Statistics

\begin{tabular}{|c|c|c|c|c|c|}
\hline & $\mathrm{N}$ & Minimum & Maximum & Mean & $\begin{array}{l}\text { Standard } \\
\text { Dev. }\end{array}$ \\
\hline $\begin{array}{l}\text { INITIAL INVESTMENTS } \\
\text { (incl. initial FEES) }\end{array}$ & 44 & .00 & 590000.00 & 81546.09 & $1.18956 \mathrm{E} 5$ \\
\hline $\begin{array}{l}\text { TRAINING DAYS (Franchisees } \\
\text { and employees) }\end{array}$ & 45 & 2.00 & 68.50 & 15.0000 & 14.76097 \\
\hline $\begin{array}{l}\text { There is a lot of trust between } \\
\text { the partners }\end{array}$ & 49 & 3 & 5 & 4.27 & .700 \\
\hline $\begin{array}{l}\text { There is an atmosphere of open- } \\
\text { ness and sincerity }\end{array}$ & 49 & 2 & 5 & 4.35 & .751 \\
\hline $\begin{array}{l}\text { Information exchange is more } \\
\text { than agreed }\end{array}$ & 49 & 3 & 5 & 4.20 & .763 \\
\hline $\begin{array}{l}\text { Partnership is on the basis of } \\
\text { cooperation }\end{array}$ & 49 & 3 & 5 & 4.59 & .574 \\
\hline TRUST & 50 & 3.20 & 5.00 & 4.4040 & .54733 \\
\hline $\begin{array}{l}\text { It is difficult to predict the be- } \\
\text { haviour of the outlet manager } \\
\text { (or franchisee) }\end{array}$ & 51 & 1 & 5 & 2.59 & 1.004 \\
\hline
\end{tabular}




\begin{tabular}{|c|c|c|c|c|c|}
\hline $\begin{array}{l}\text { It is difficult to control the be- } \\
\text { haviour of the outlet manager } \\
\text { (or franchisee) }\end{array}$ & 51 & 1 & 5 & 2.10 & 1.044 \\
\hline $\begin{array}{l}\text { It is difficult to evaluate per- } \\
\text { formance of the outlet manager } \\
\text { (or franchisee) }\end{array}$ & 51 & 1 & 4 & 2.25 & .744 \\
\hline $\begin{array}{l}\text { It is difficult to measure the lo- } \\
\text { cal services }\end{array}$ & 51 & 1 & 5 & 2.08 & .977 \\
\hline $\begin{array}{l}\text { BEHAVIOURAL } \\
\text { UNCERTAINTY }\end{array}$ & 51 & 1.00 & 4.25 & 2.2549 & .77054 \\
\hline $\begin{array}{l}\text { CD-CAPABILITIES (Age of } \\
\text { the Franchise System) }\end{array}$ & 50 & 1 & 29.00 & 9.8400 & 7.58183 \\
\hline $\begin{array}{l}\text { ENVIRONMENTAL } \\
\text { UNCERTAINTY (Contract Du- } \\
\text { ration in years) }\end{array}$ & 47 & 1 & 20 & 7.83 & 4.493 \\
\hline
\end{tabular}

To test the hypotheses we carry out a regression analysis. We conduct an OLS regression analysis with COMPLETENESS as dependent variable. The explanatory variables refer to trust (TRUST), behavioral uncertainty (BEH_UNCERTAINTY), environmental uncertainty (ENV_UNCERTAINTY), franchisee's specific investments (SPECIFIC_INVESTMENTS), intangible system-specific assets (INTANGIBLE_SYSTEM ASSETS) and contract design capabilities (CDCAPABILITIES). Table 2 presents the correlations of the variables used in the regression analysis. In addition, the variance inflation factors are well below the rule-of-thumb cut-off of 10 (Neter et al. 1985). We do not find any collinearity indication.

Table 2. Correlations

\begin{tabular}{|c|c|c|c|c|c|c|c|}
\hline & 1 & 2 & 3 & 4 & 5 & 6 & 7 \\
\hline $\begin{array}{l}\text { ENVIR_ } \\
\text { UNCERTAINTY }\end{array}$ & 1.000 & & & & & & \\
\hline $\begin{array}{l}\text { BEHAV } \\
\text { UNCERTAINTY }\end{array}$ & -.249 & 1.000 & & & & & \\
\hline TRUST & $.320^{*}$ & $-.304^{*}$ & 1.000 & & & & \\
\hline $\begin{array}{l}\text { CD- } \\
\text { CAPABILITIES }\end{array}$ & .022 & -.011 & .122 & 1.000 & & & \\
\hline $\begin{array}{l}\text { INTANGIBLE } \\
\text { SYSTEM_- } \\
\text { ASSETS }\end{array}$ & .176 & $-.365^{*}$ & .217 & .001 & 1.000 & & \\
\hline $\begin{array}{l}\text { SPECIFIC } \\
\text { INVESTMENTS }\end{array}$ & $.478^{* *}$ & $-.466^{* *}$ & .269 & .291 & .259 & 1.000 & \\
\hline COMPLETENESS & .063 & $-.296^{*}$ & $.302^{*}$ & .105 & .009 & .168 & 1.000 \\
\hline
\end{tabular}


**. Correlation is significant at the 0.01 level (2-tailed).

We estimate the following regression equation:

COMPLETENESS $=\alpha+\beta_{1}$ TRUST $+\beta_{2}$ BEHAV_UNCERTAINTY +
$\beta_{3}$ ENV_UNCERTAINTY $+\beta_{4}$ SPECIFIC_INVESTMENTS +
$\beta_{5}$ INTANGIBLE_SYSTEM ASSETS $+\beta_{6}$ CD-CAPABILITIES

According to the relational view of governance, COMPLETENESS varies positively or negatively with trust. Under substitutability view, trust reduces relational risk and decreases contractual completeness; under complementarity view, trust enables knowledge sharing and increases contractual completeness. According to the agency theory, completeness varies negatively with behavioral uncertainty. Based on transaction cost theory, environmental uncertainty is negatively related with completeness because it is not possible or very costly for the franchisor to preplan all relevant actions under a complex and changing transactional environment. Furthermore, completeness varies negatively with franchisees' specific investments due to the hostage effect of franchisees' specific investments. According to the property rights view, completeness varies negatively with intangibility of system-specific assets. Finally, the development of contract design capabilities is positively related with completeness of contracts, due to interorganizational learning.

Table 4 reports the results of regression analysis. The coefficient of trust (TRUST) is positive and highly significant. This is consistent with our complementarity view that an increase in trust enables the franchisor to design more refined contract terms. The coefficient of behavioral uncertainty (BEHAV_UNCERTAINTY) is negative and significant. This implies that high behavioral uncertainty results in high monitoring costs preventing the franchisor from designing more complete contracts. The coefficient of intangible systemspecific assets (INTANGIBLE_SYSTEM ASSETS) is negative and significant indicating that higher intangibility of system-specific assets results in less complete contracts. In addition, the coefficient of contract design capabilities (CDCAPABILITIES) is compatible with the view that interorganizational learning increases contractual completeness. Furthermore, the coefficient of environmental uncertainty (ENV_UNCERTAINTY) is negative as expected but not significant. Finally, the coefficient of franchisee's specific investments (SPECIFIC_INVESTMENTS) is not significant.

Table 4. Regression results

\begin{tabular}{lc}
\hline COMPLETENESS & \\
\hline Intercept & 2.438 \\
& $(1.514)$ \\
TRUST & $0.709^{* *}$ \\
\hline
\end{tabular}




\begin{tabular}{lc}
\hline & $(0.325)$ \\
BEHAV_UNCERTAINTY & $-0.579^{* *}$ \\
ENVIR_UNCERTAINTY & $(0.22)$ \\
& -0.042 \\
SPECIFIC_INVESTMENTS & $(0.05)$ \\
INTANGIBLE & $3.219 \mathrm{E}-007$ \\
SYSTEM_ASSETS & $(0.000)$ \\
& $-0.039^{* *}$ \\
CD-CAPABILITIES & $(0.015)$ \\
& 0.225 \\
& $(0.157)$ \\
\hline & F $=4.041^{* * *}$ \\
& Adj. R Square \\
& 0.378 \\
& $\mathrm{~N}=44$
\end{tabular}

${ }^{* * *} \mathrm{p}<0.01 ;{ }^{* *} \mathrm{p}<0.05 ;{ }^{*} \mathrm{p}<0.1$; values in parentheses are standard errors.

\subsection{Discussion and Conclusion}

The goal of the paper is to explain the degree of contractual completeness in franchising by developing and testing hypotheses derived from transaction cost theory, agency theory, property rights theory, organizational capability theory and the relational view of governance. First, starting from the recent literature on contractual completeness and complexity that shows that contractual completeness is a heterogeneous concept without sufficient theoretical foundation, we develop the concept of contractual completeness based on the property rights view of allocation of specific and residual decision rights between contract partners. Contractual completeness is defined by the ratio between specific rights and residual decision rights stipulated in contracts. The higher (lower) this ratio, the more (in-) complete is the contract. Second, we develop and test the following hypotheses about contractual completeness in franchising: According to the agency theory, completeness varies negatively with behavioural uncertainty. The results provide support for the hypothesis that measurement difficulties, due to behavioural uncertainty, result in a lower degree of contractual completeness. Based on the relational view of governance, we investigate the relationship between trust and the degree of contractual completeness. Our data support the complementarity hypothesis that trust enables the franchisor to design more complete contracts. Further we examine the property rights hypothesis that completeness varies negatively with intangibility of system-specific assets. The results indicate that non-contractible sys- 
tem-specific know-how results in difficulties explicitly specifying the use of system know-how in the franchise contract and hence in a lower degree of contractual completeness. In addition, based on the organizational capability view, we show that contract design capabilities and contractual completeness are positively related but the coefficient is not significant. Finally, the data from the Austrian franchise sector do not confirm the transaction costs hypotheses that completeness varies negatively with the franchisee's specific investments and environmental uncertainty.

How does our study extend the results in the literature? The major contribution of our study is first the clarification of the relationship between contractual completeness, decision rights, and complexity, and second the explanation of the determinants of contractual completeness in franchise relationships by applying transaction cost theory, agency theory, property rights theory, relational view of governance and organizational capability theory.

What are the business/managerial implications of (the degree of) contractual completeness in franchising? We limit ourselves to two observations. First, the design of contracts is the most important organizational task in franchising. A choice has therefore to be made which aspects to include in the contract. Our study may be helpful in this respect because it has identified a number of the determinants of contractual completeness and the direction of their effect. Second, the coverage of the business format by formulating specific and residual rights varies between franchises. Kaufmann and Eroglu (1998) stated therefore that "[o]f the many types of management issues faced by franchisors, perhaps one of the most difficult is defining the appropriate boundaries of their format, i.e., maintaining the required level of uniformity for the system to obtain economies of scale, while avoiding the danger of stifling efficient local market adaptation”. Our study has provided a start to make concepts like the boundary of a business format and the required level of uniformity measurable by proposing to use the various rights specified in actual franchise contracts.

However, this study has important limitations: Due to the small sample size the generalizability of the results is limited; further research analysing data from other countries with a larger number of franchise systems would help ascertain generalizability of our research results. In addition, environmental uncertainty should be measured by a multiple-item scale since contract duration may result in endogenity problems. Furthermore, the measurement of contractual completeness is not without limitations; it is a first step to measure contractual completeness. In future studies, we will use a multiple-item scale that differentiates between specific decision rights and residual decision rights specified in the franchise contract. In addition, the development of a more valid indicator for contractual completeness requires the use of more objective measures based on contract data. The collection of contract data is an important issue for future research. 


\section{References}

Aghion P, Dewatripont M, Rey P (2004) Transferable control. Journal of the European Economic Association 2: 115 - 138

Al-Najjar N (1995) Incomplete contracts and the governance of complex contractual relationships. American Economic Review 85: 432-436

Anderson E (1985) The Sales person as outside agent or employee: A transaction cost analysis, Marketing Science 4: $234-254$

Argyres N, Mayer KJ (2007) Contract design as firm capability: An integration of learning and transaction cost Perspectives. Academy of Management Review 32: 1060 - 1077

Argyres N, Bercovitz J, Mayer K (2007) Complementarity and evolution of contractual provisions: An empirical study of IT services contracts. Organization Science 18: 3-19

Ariño A, Reuer J (2005) Alliance contractual design, in: Handbook of strategic alliances, 149-167

Armstrong JS, Overton TS (1977) Estimating non-response bias in mail surveys. Journal of Marketing Research 14(3): 396-402

Baker GP, Gibbons R, Murphy KJ (2008) Strategic alliances: Bridges between 'islands of conscious power'. Journal of the Japanese and International Economies 22(2): 146-163

Barney J (1991) Firm resources and sustained competitive advantage. Journal of Management 17(1): 99-120

Barthelemy J, Quelin B (2006) Complexity of outsourcing contracts and ex post transaction costs: An empirical investigation. Journal of Management Studies 43: 1775-1797

Barzel Y ( 1982) Measurement cost and the organization of markets. Journal of Law and Economics 25(1): 27-48

Bernheim BD,Whinston MD (1998) Incomplete contracts and strategic ambiguity. American Economic Review 88: $902-32$

Blomqvist K, Hurmelinna P, Seppänen R (2005) Playing the collaboration game right - balancing trust and contracting. Technovation 25: $497-504$

Bohnet I, Baytelman Y (2007) Institutions and trust: Implications for preferences, beliefs and behaviour. Rationality and Society 19: $99-135$

Bolton P, Faure-Grimaud A (2005) Thinking ahead: The decision problem. Working Paper Columbia Business School

Bolton P, Dewatripont M (2005) Contract theory, MIT Press

Bolton P, Faure-Grimaud A (2009) Satisficing contracts, NBER working paper 14654

Brickley JA, Linck JS, Smith CW (2003) Boundaries of the firm: Evidence from the banking industry. Journal of Financial Economics 70: 351 - 383

Crocker K, Masten SE (1991) Pretia ex machina? Prices and process in long-term contracts. Journal of Law and Economics 34: 69 - 99

Crocker K, Reynolds K (1993) The efficiency of incomplete contracts: An empirical analysis of air force engine procurement. Rand Journal of Economics 24: 126-146

Demsetz H (1998) Book review: Firms, contracts and financial structure (by O. Hart). Journal of Political Economy 106: 446 - 452

Dessein W, Santos T (2006) Adaptive organizations. Journal of Political Economy 14(5): 956-95

Dyer J, Singh H (1998) The relational view: Cooperative strategy and sources of interorganizational competitive advantage. Academy of Management Review 23: 660-67

Dyer J, Chu W (2000) The determinants of trust in supplier-automaker relationships in the U.S., Japan, and Korea. Journal of International Business Studies 31: 259 - 285

Eggleston K, Posner EA, Zeckhauser R (2000) The design and interpretation of contracts: Why complexity matters. New York University Law Review 95: 91 - 132 
Fowler F J (1993) Survey research methods. Sage Publications: Newbury Park

Furlotti M (2007) There is more to contracts than incompleteness: A review and assessment of empirical research on inter-firm contracts. Journal of Management \& Governance 11: $61-99$

Gibbons R (2005) Four formal(izable) theories of the firm? Journal of economic behavior and organization 58: $200-245$

Gilson RJ, Sabel CF, Scott RE (2009) Contracting for innovation: Vertical disintegration and interfirm collaboration. Columbia Law Review 109: 431 - 502

Grossman SJ, Hart OD (1986) The Cost and benefits of ownership: a theory of vertical and lateral integration. Journal of Political Economy 94(4): 691-719

Gulati R (1995) Does familarity breed trust? The implications of repeated ties for contractual choice in alliances. Academy of Management Journal 38(1): 85 -112

Gulati R, Sytch M (2008) Does familiarity breed trust? Revisiting the antecedents of trust. Managerial and Decision Economics 29: 165 - 190

Gulati R, Nickerson J (2008) Interorganizational trust, governance choice and exchange performance. Organization Science 19: 688-708

Hadfield GK (1990) Problematic relations: Franchising and the law of incomplete contracts. Stanford Law Review 42: 927 - 992

Hagedoorn J, Hesen G (2008) Contractual complexity and the cognitive load of R\&D alliance contracts. Working Paper, University of Maastricht

Hansen ZK, Higgins MJ (2007) The effect of contractual complexity on technology sourcing agreements. Working Paper, Georgia Institute of Technology

Hart O, Moore J (1990) Property rights and the nature of the firm. Journal of Political Economy 98(6): 1119-1158

Hart O, Moore J, (2008) Contracts as reference points. Quarterly Journal of Economics 123(1): $1-48$

Heide J, John G (1990) Alliances in industrial purchasing: The determinants of joint action in buyer-supplier relationships. Journal of Marketing Research 27: 24 - 36

Helfat C E, Finkelstein, Mitchell SW, Peteraf MA, Singh H, Teece DJ,Winter SG (2007) Dynamic capabilities: Understanding strategic change in organizations. Blackwell: Oxford

Hendrikse G, Hu Y (2009) Incompleteness of chinese fruit and vegetable contract. ISNIEConference, June 2009

Hendrikse G,Windsperger J (2009/10) On network governance. International Studies of Management and Organization 39: $3-7$

Holmstrom B, Milgrom P (1991) Multi-task principal-agent Analyses: Incentive contracts, asset ownership, and job design. Journal of Law, Economics and Organization 7: $24-$ 52

Hu Y, Hendrikse G (2009/10) Allocation of decision rights in fruit and vegetable contracts in China. International Studies of Management and Organization 39: 8 - 30

John G, Reve T (1982) The reliability and validity of key informant data from dyadic relationships in marketing channels. Journal of Marketing Research 19(4): 517 - 524

John G, Weitz BA (1989) Sales force compensation: An empirical investigation of factors related to use of salary versus incentive compensation. Journal of Marketing Research 26: $1-14$

Joskow PL (1985) Vertical integration and long-term contracts: The case of coal-burning electric generating plants. Journal of Law, Economics \& Organization 1: 33 - 80

Kalnins A, Mayer KL (2004) Relationships and hybrid contracts: An analysis of contract choice in information technology. Journal of Law, Economics \& Organization 20: 207 229 
Kaplow L (1992) Rules versus standards: An economic analysis. Duke Law Journal 42: 557 $-629$

Kaufmann PJ, Eroglu S (1998) Standardization and adaptation in business format franchising, Journal of Business Venturing 14: 69-85

Klein B (1980) Transaction cost determinants of "unfair” contractual arrangements. American Economic Review 70: 356-362

Klein B. (1996) Why hold-ups occur: The self-enforcing range of contractual relationships. Economic Inquiry 34: 444 - 463

Klein B (2000) The role of incomplete contracts in self-enforcing relationships. Revue d' Economie Industrielle 92: 67 - 80

Klein B, Murphy K (1997) Vertical integration as a self-enforcing contractual arrangement. American Economic Review 87: 415-420

Klein B, Crawford R, Alchian A (1978) Vertical integration, appropriable rents and the competitive contracting process. Journal of Law and Economics 21: 297-326

Klick J, Kobayashi BH, Ribstein LE (2006) Incomplete contracts and opportunism in franchise arrangement. American, Law \& Economics Association Annual Meetings, Working Paper 61

Lafontaine F (1992) Agency theory and franchising: Some empirical results. Rand Journal of Economics 23: 263-283

Lafontaine F, Slade ME (1998) Incentive contracting and the franchise decision, in Advances in business applications of game theory, K. Chatterjee, W. Samuelson (eds.), Kluwer Academic Press

Lazzarini SG, Miller GJ, Zenger TR (2008) Dealing with the paradox of embeddedness: The role of contracts and trust in facilitating movement out of committed relationships. Organization Science 19: 709 - 728

Lerner J, Malmendier U (2010) Contractibility and the design of research agreements. American Economic Review 100, 1 (forthcoming)

Luo Y (2002) Contract, cooperation and performance in international joint ventures. Strategic Management Journal 23: 903-919

Masten SE, Saussier S (2000) Econometrics of contracts: An assessment of developments in the empirical literature on contracting. Revue d'Economie Industrielle 92: 215 - 236

Macneil I (1978) Contracts: Adjustments of long-term economic relations under classical, neoclassical and relational contract law. Northwestern University Law Review 72: 854906

Mayer K, Argyres N (2004) Learning to contract: Evidence from the personal computer industry. Organization Science 14: 394-410

Mellewigt T, Madhok A, Weibel A (2007) Trust and formal contracts in interorganizational relationships - substitutes and complements. Managerial and Decision Economics 28: 833-847

Mesquita L, Brush T (2008) Untangling safeguard and production coordination effects in long-term buyer-supplier relationship. Academy of Management Journal 51: 785-807

Milgrom P, Roberts J (1992) Economics, organizations and management. Prentice-Hall International Editions: Homewood

Netter J,Wasserman W, Kutner MH (1985) Applied linear statistical models. Irwin: Homewood, IL

Nonaka I (1994) A dynamic theory of organizational knowledge creation. Organization Science 5(1): 14-37

Parkhe A (1993): Strategic alliance structuring: A game theoretic and transaction costs examination of interfirm cooperation. Academy of Management Journal 36: 794-829 
Podsakoff PM, MacKenzie SB, Podsakoff NP, Lee J-Y (2003) Common method biases in behavioral research: A critical review of the literature and recommended remedies. Journal of Applied Psychology 88: 879-903

Poppo L, Zenger TR (2002) Do formal contracts and relational governance function as substitutes or complements? Strategic Management Journal 23: 90 -118

Reuer J, Ariño A (2002): Contractual renegotiations in strategic alliances. Journal of Management 28: 51-74

Reuer J, Ariño A (2007) Strategic alliance contracts: Dimensions and determinants of contractual complexity. Strategic Management Journal 28: 313-330

Reuer J, Ariño A, Mellewigt T (2006) Entrepreneurial alliances as contractual forms. Journal of Business Venturing 21: 306-325

Roberts J (2000) From know-how to show-how: Questioning the role of information and communication technologies in knowledge transfer. Technology Analysis \& Strategic Management 12(4): $429-443$

Ryall M, Sampson CR (2006) Do prior alliances influence contract structure? in Ariño A, Reuer J (eds.) Strategic alliances. Houndsmills: Palgrave MacMillian

Ryall M, Sampson CR (2009) Formal contracts in the presence of relational enforcement mechanisms. Management Science 55: 906 - 925

Saussier S (2000) Transaction costs and contractual incompleteness: The case of electricité de France. Journal of Economic Behavior and Organization 42: 189 - 206

Scott RE (2006) The law and economics of incomplete contract. Annual Review of Law and Social Sciences 2: $279-297$

Scott RE, Triantis GG (2005) Incomplete contracts and the theory of contract design. University of Virginia Law School Working Paper 23

Seppänen R, Blomqvist K, Sundqvist S (2007) Measuring inter-organizational trust - a critical review of the empirical research in 1990 - 2003. Industrial Marketing Management 36: $249-265$

Simon HA (1951) A formal theory of the employment relationship. Econometrica 19: 293 305

Simonin BL (1999a) Ambiguity and the process of knowledge transfer in strategic alliances. Strategic Management Journal 20(7): 595-623

Simonin BL (1999b) Transfer of marketing know-how in international strategic alliances: An empirical investigation of the role and antecedents of knowledge ambiguity. Journal of International Business Studies 30(3): 463-490

Tadelis S (2002) Complexity, flexibility, and the make-or-buy decision. American Economic Review 92(2): 433-437

Teece DJ (2007) Explicating dynamic capabilities: the nature and microfoundations of (sustainable) enterprise performance. Strategic Management Journal 28: 1319 - 1350

Tirole J (2009) Cognition and incomplete contract. American Economic Review 99: 265 294

Williamson OE (1975) Market and hierarchies: Analysis and antitrust implications, New York

Williamson OE (1985) The economic institutions of capitalism. Free Press

Windsperger J (1994) The evolution of the vertically integrated firm: A transaction cost analysis. In: Aiginger K, Finsinger J (eds.) Applied industrial organization. Dordrecht: $111-130$

Windsperger J (2004) The dual network structure of franchising firms: Property rights, resource scarcity and transaction cost explanations. In: Windsperger J, Cliquet G, Hendrikse G, Tuunanen $M$ (eds.) Economics and management of franchising networks. Heidelberg: $69-88$ 
Windsperger J (2009) Allocation of decision rights in joint ventures. Managerial and Decision Economics 30: $491-501$

Yu C-MJ, Liao T-J, Lin Z-D (2006) Formal governance mechanisms, relational governance mechanisms, and transactions-specific investments in supplier-manufacturer relationships. International Marketing Management 35: 128 - 139

Appendix: Measures of Variables

\begin{tabular}{|c|c|}
\hline $\begin{array}{l}\text { COMPLETENESS } \\
\text { (contractual completeness) }\end{array}$ & $\begin{array}{l}\text { The franchisor has to evaluate contractual completeness on a } 5 \\
\text { point scale (1, strongly disagree; ...5, strongly agree): } \\
\text { The cooperation between the franchisor and the franchisee is } \\
\text { regulated in a detailed manner in the contract. }\end{array}$ \\
\hline \multirow{2}{*}{$\begin{array}{l}\text { TRUST (trust) } \\
\text { Coefficient alpha: } 0.86\end{array}$} & $\begin{array}{l}\text { The franchisor has to evaluate trust on a } 5 \text { point scale } \\
\text { (1, strongly disagree; ...5, strongly agree): }\end{array}$ \\
\hline & $\begin{array}{l}\text { There is a lot of trust between the partners. } \\
\text { There is an atmosphere of openness and sincerity. } \\
\text { Information exchange is more than agreed. } \\
\text { Cooperation is on the basis of partnership. }\end{array}$ \\
\hline \multirow[t]{2}{*}{$\begin{array}{l}\text { BEHAV_UNCERTAINTY } \\
\text { (behavioral uncertainty) }\end{array}$} & $\begin{array}{l}\text { The franchisor has to evaluate behavioral uncertainty on a } 5 \text { point } \\
\text { scale (1, strongly disagree; ...5, strongly agree): }\end{array}$ \\
\hline & $\begin{array}{l}\text { It is difficult to predict the behaviour of the outlet manager (or } \\
\text { franchisee). }\end{array}$ \\
\hline
\end{tabular}




\begin{tabular}{|l|l|}
\hline & $\begin{array}{l}\text { It is difficult to control the behaviour of the outlet manager (or } \\
\text { franchisee). } \\
\text { It is difficult to evaluate performance of the outlet manager (or } \\
\text { franchisee). } \\
\text { It is difficult to measure the local services. }\end{array}$ \\
\hline $\begin{array}{l}\text { ENVIR_UNCERTAINTY } \\
\text { (environmental uncertainty) }\end{array}$ & $\begin{array}{l}\text { Environmental uncertainty is measured by the contract duration } \\
\text { (in years). }\end{array}$ \\
\hline $\begin{array}{l}\text { SPECIFIC_INVESTMENTS } \\
\text { (franchisee's specific invest- } \\
\text { ments) }\end{array}$ & $\begin{array}{l}\text { Franchisee's specific investments are measured by the sum of ini- } \\
\text { tial fees and initial investments. }\end{array}$ \\
\hline $\begin{array}{l}\text { INTANGIBLE_SYSTEM } \\
\text { ASSETS (intangible system- } \\
\text { specific assets of the franchisor) }\end{array}$ & Total training days of the franchisee and its employees (per year). \\
\hline $\begin{array}{l}\text { CD-CAPABILITIES } \\
\text { (contract design capabilities) }\end{array}$ & $\begin{array}{l}\text { Natural log of years since opening the first franchise outlet in Aus- } \\
\text { tria. }\end{array}$ \\
\hline
\end{tabular}




\section{Publications in the ERIM Report Series Research* in Management}

\section{ERIM Research Program: "Organizing for Performance"}

\section{0}

Investigating the Perceptions of Credit Constraints in the European Union

Erik Canton, Isabel Grilo, Josefa Monteagudo, and Peter van der Zwan

ERS-2010-001-ORG

http://hdl.handle.net/1765/17699

Two Lighthouses to Navigate: Effects of Ideal and Counter-Ideal Values on Follower Identification and Satisfaction with their Leaders

Niels van Quaquebeke, Rudolf Kerschreiter, Alice E. Buxton, and Rolf van Dick

ERS-2010-003-ORG

http://hdl.handle.net/1765/17702

Genome-wide Association Studies and the Genetics of Entrepreneurship

Matthijs J.H.M. van der Loos, Philipp D. Koellinger, Patrick J.F. Groenen, and A. Roy Thurik

ERS-2010-004-ORG

http://hdl.handle.net/1765/17757

How embodied cognitions affect judgments: Height-related attribution bias in football foul calls

Niels van Quaquebeke and Steffen R. Giessner

ERS-2010-006-ORG

http://hdl.handle.net/1765/17827

Flexible Labor and Innovation Performance: Evidence from Longitudinal Firm-Level Data

Haibo Zhou, Ronald Dekker, and Alfred Kleinknecht

ERS-2010-007-ORG

http://hdl.handle.net/1765/18037

The Influence of Installed Technologies on Future Adoption Decisions: Empirical Evidence from E-Business

Philipp Koellinger and Christian Schade

ERS-2010-012-ORG

http://hdl.handle.net/1765/18463

Seeds of Regional Structural Change: The Role of Entrepreneurs and Expanding Firms in Shaping Local Path Dependencies Frank Neffke and Martin Henning

ERS-2010-014-ORG

http://hdl.handle.net/1765/19207

Determinants of Contractual Completeness in Franchising

George Hendrikse and Josef Windsperger

ERS-2010-017-ORG

http://hdl.handle.net/1765/19424

* A complete overview of the ERIM Report Series Research in Management:

https://ep.eur.nl/handle/1765/1

ERIM Research Programs:

LIS Business Processes, Logistics and Information Systems

ORG Organizing for Performance

MKT Marketing

F\&A Finance and Accounting

STR Strategy and Entrepreneurship 